Available Online at http:// www.bioline.org.br/ja
J. Appl. Sci. Environ. Mgt. 2004

Vol. 8 (1) 49 - 53

\title{
Physico-chemical and Mineralogical Characterisation of Subsurface Sediments around Gaborone Landfill, Botswana
}

\author{
*NGOLE, V M${ }^{1}$; TOTOLO, ${ }^{1}$; EKOSSE, G E ${ }^{2}$
}

${ }^{1}$ Department of Environmental Science, ${ }^{2}$ Department of Geology,

University of Botswana, Private bag, 0022, Gaborone Botswana

\begin{abstract}
Studies were carried out on subsurface sediments obtained around the Gaborone landfill area Botswana, in order to characterize their mineralogy and physico-chemistry, appraise any contaminant inputs from the landfill and assess their ability to attenuate contaminants from the landfill. Physico-chemical properties investigated included particle size distribution (PSD), moisture content, bulk density $\left(\mathrm{D}_{\mathrm{b}}\right)$, porosity, surface area, $\mathrm{pH}$, electrical conductivity (EC), and cation exchange capacity (CEC). The mineral phases occurring in the subsurface sediments were identified by use of X-ray powder diffraction (XRPD) technique. Grain size analyses of the subsurface sediments revealed sandy loam, silty loam, and silt as the main textural classes. The values obtained for $\mathrm{D}_{b}$ and porosity is reflective of the textural classes of the different samples. Moisture content values of the studied samples are characteristic of sediments in semi-arid environments. Apart from two samples, which were acidic, others were alkaline. The EC values were indicative of significant amounts of total dissolved salts (TDS) especially along the eastern corner of the landfill. Cation exchange capacity values were relatively low. Minerals identified by XRPD included quartz, microcline, muscovite and kaolinite in bulk subsurface sediments, whereas kaolinite, smectite and /or illite occurred in the clay fractions. Sediment $\mathrm{pH}$, EC and TDS suggests inputs from the landfill. The sediments seem to have a low attenuation capacity as a result of their physico-chemical and mineralogical properties. Further geophysical and hydrogeochemical research is needed to verify if the Gaborone landfill area is environmentally safe. @JASEM
\end{abstract}

Environmentally safe landfilling of waste is based on technologies that aim at protecting aquifers, reducing gaseous emissions, and curbing the spread of leachate whereas poor waste disposal practices are usually caused by weak environmental protection standards. In several cases, this leads to leachate from landfill sites to migrate and affect the quality of soil and water resources in the vicinity (Rushbrock, 1997). To minimize the negative impacts of landfilling on the surrounding environment, the underlying and surrounding soil strata of the landfill should have the ability to retard contaminant spread within the surrounding environment. This capacity is determined by the physico-chemical and mineralogical properties of the sediment strata (Thornton et al., 2000).

Gaborone Landfill which became operational in 1994 is a municipal solid waste landfill located south east of Gaborone city, the capital of Botswana (Figure 1).

\footnotetext{
*Corresponding author: E-mail: ngolevm@mopipi.ub.bw
}

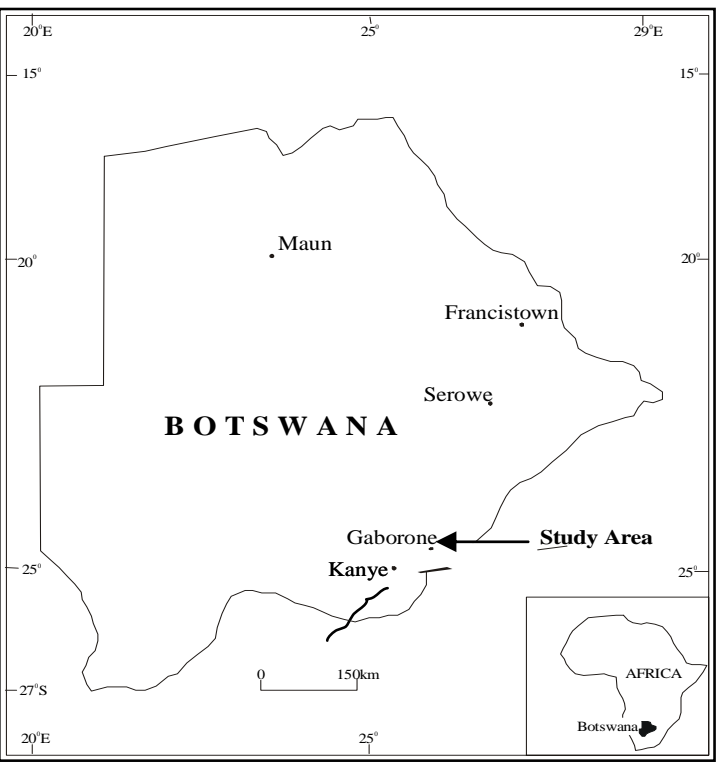

Fig 1: Map of Botswana showing the study area 
The landfill covers an area of about $204800 \mathrm{~m}^{2}$ with a topographic gradient of 1.77 from west to east. It is underlain by the Thamaga Granite of the Gaborone Granite Complex (GGC), which is composed of varying percentages of quartz, orthoclase, microcline, muscovite, albite, and plagioclase. Sediments around Gaborone Landfill consist of coarse-grained sands, which become clayey and plastic with depth (Arup, 1994). Permeability of sediments around the Gaborone landfill prior to its construction ranged from $2.3 \times 10-8 \mathrm{~ms}^{-2}$ to $5.7 \times 10-7 \mathrm{~ms}^{-2}$ at depths between $1.3 \mathrm{~m}$ and $4.0 \mathrm{~m}$ Arup (1994). The permanent water table around the landfill according to Arup (1994) varies from $4.48 \mathrm{~m}$ to $7.86 \mathrm{~m}$ below the ground surface. Gaborone Dam reservoir and Notwane River are the two permanent surface water bodies around the landfill area. The landfill is not lined; consequently, there is a risk of groundwater contamination from leachate. Apart from site investigations which included determination of site boundaries and topography, stress tests to assess mass permeability, and suitability of excavated soils for use as sub tip liner and cover material, carried out before its design (Arup, 1994), the other documented study focused on aquifer mineralogy and geophysical characterization of the subsurface environment around the landfill (Bogatsu et al., 1999; 2000). No other research has been conducted to characterize the subsurface sediments around the Gaborone Landfill area in order to establish whether landfilling of waste would be environmentally safe. The main objective of this work was to study the physico-chemical properties and identify the mineral composition of subsurface sediments around the Gaborone Landfill Botswana, in an endeavor to appraise their capacity to attenuate contaminants emanating from the landfill and to determine possible contaminant inputs resulting from landfilling activities.

\section{MATERIAL AND METHODS}

Fifty-seven subsurface sediment samples were collected at a $50 \mathrm{~cm}$ depth interval from eleven profiles; ten (P 2 - P 11) spread around the landfill vicinity, and one (P 1) located about $6 \mathrm{~km}$ northeast of the landfill. Samples from P 1 were selected as baseline samples because this profile was located in a relatively undisturbed area outside the main study site but having the same geologic formation and lithology. The PSD of the samples was determined by both wet and dry sieving as well as centrifuging using a Retsch AS 200 Basic Analytical Sieve Shaker, a nest of sieves with respective mesh sizes, and an SA CP4 Schimadzu Centrifugal Particle Size Analyzer respectively (Okalebo et al., 1993; van Reeuwijk, 1993). The soil moisture content and $D_{b}$ were determined according to the methods highlighted by Tan, (1996). Soil porosity was calculated from $D_{b}$ values as explained by Brady and Weil, (1999). The $\mathrm{pH}$ of samples was determined with a $\mathrm{pH}$ Meter both in a 1:2.5 sediment: water and sediment : $1 \mathrm{M} \mathrm{KCl}$ mixture as described by van Reeuwjik, (1993) and Igwe et al., (1999). Sediment EC was determined in the same $1: 2.5$ sediment : water suspension used for $\mathrm{pH}$ determination with a conductivity-meter (Okalebo et al., 1993). The amounts of total dissolved salts in the samples were estimated from the EC values obtained (Ekosse, 2000; Sparks, 1995). The barium chloride-triethanolamine method as described by Hendershot and Duquette, (1986); and $\mathrm{Ma}$ and Eggleton, (1999) was used to determine the CEC of the samples. The mineral composition in both the bulk subsurface sediments as well as their clay fractions was identified with a Philips PW 3710 XRPD unit and a 1999 version of Philips X'PERT Graphics and Identify Software package according to methods described by Ekosse, (2000) and Melkerud et al., (2000).

\section{RESULTS AND DISCUSSION}

Sandy loam, silty loam and silt are the main textural classes of the subsurface sediments as confirmed by Ngole et al., (2002) in a related study. Lack of uniformity in the PSD of sediments along different profiles (Figure 2) and the smooth and rounded pebbles observed could indicate alluvial transport from elsewhere. They could also have been deposited as a result of translocation from surface to bottom horizon through the cracks caused by the swelling and shrinkage of the smectitic sediments especially along the eastern corner of the landfill. The coarse nature of the sediments does not constitute an effective hydraulic barrier. The thin-layered sediments characteristic of the landfill environment may also encourage horizontal and lateral migration of contaminants along the sediment-bedrock interface. Notwane River at the bottom of the slope of the landfill is at risk of contamination. The percent moisture content of studied samples range from 0.36 $\%$ (P 3) to $5.46 \%$ (P 9). At the control site (P 1), the percent moisture content was between 0.63 and 4.02. Sediment moisture content values are typical of soils of semi-arid environments (Ringrose et. al., 1995). Bulk density values were between 1.12 (P 5) and 1.55 (P 3), with an outlier value of 2.04 (P 2). The lowest porosity value was $41.32 \%(\mathrm{P} 3)$, whereas the highest was 57.61 (P 5). At P 1, the porosity values were between $49.08 \%$ and $61.74 \%$. $\mathrm{D}_{\mathrm{b}}$ values obtained for the studied sediments are classified as low, which are characteristic of sands, and sandy loam soils (Tan, 1996). They are generally well aerated allowing for migration of fluids. This is further substantiated by the values of porosity obtained for the sediments. Sediments around the Gabororne landfill were more alkaline than those 
from the control profile (Table 1). The alkaline conditions that prevail within the sediments may reduce the spread of heavy metal ions due to precipitation (Alloway and Ayres, 1997; Christensen et al., 1996; Wilcke and Kaupenjoham, 1994).

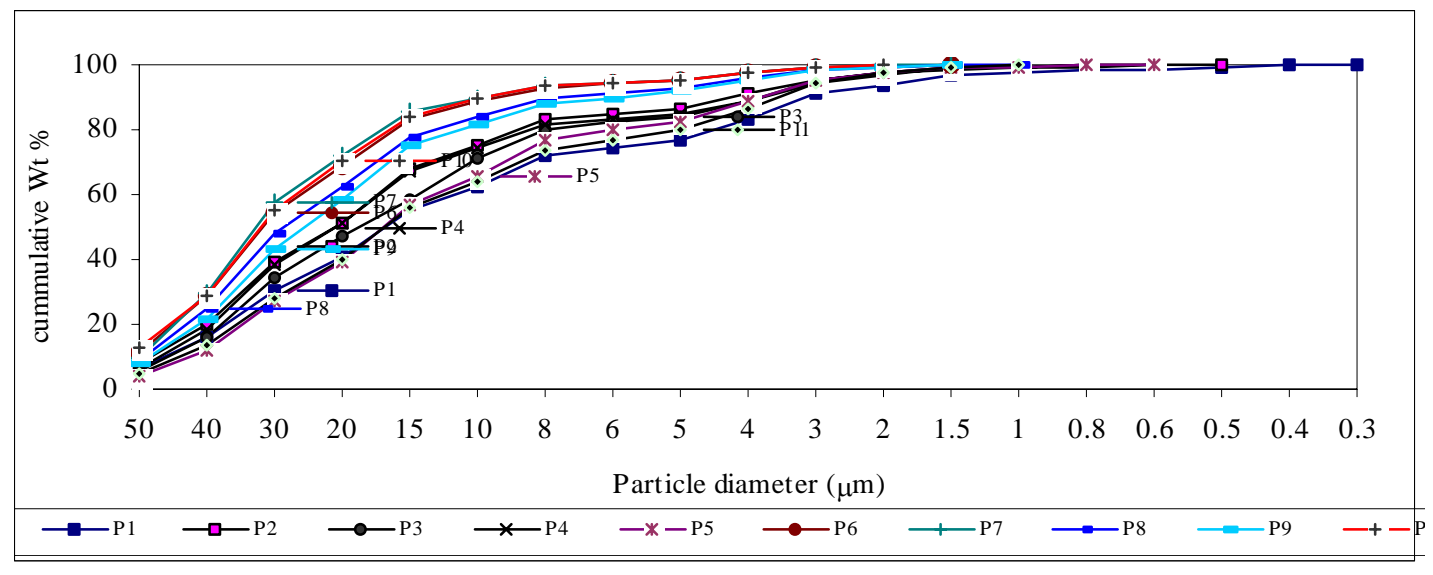

Fig 2: Mean cumulative particle size distribution along profiles

Table 1: Mean EC, pH, CEC, $\mathrm{D}_{\mathrm{b}}$ and \%pore space along profiles

\begin{tabular}{|c|c|c|c|c|c|c|}
\hline \multirow[t]{2}{*}{ Profile } & \multirow{2}{*}{$\begin{array}{c}\text { Mean } \\
\text { EC } \\
(\mu \mathrm{S} / \mathrm{cm})\end{array}$} & \multicolumn{2}{|c|}{ Mean pH } & \multirow{2}{*}{$\begin{array}{c}\text { Mean } \\
\text { CEC } \\
\text { (meq/ } \\
\text { 100g soil) }\end{array}$} & \multirow{2}{*}{$\begin{array}{c}D_{b} \\
\left(g / \mathrm{cm}^{3}\right)\end{array}$} & \multirow{2}{*}{$\begin{array}{c}\% \text { Pore } \\
\text { space }\end{array}$} \\
\hline & & $\mathrm{KCl}$ & $\mathrm{H}_{2} \mathrm{O}$ & & & \\
\hline 1 & 122.32 & 6.97 & 7.54 & 21.36 & 1.19 & 55.03 \\
\hline 2 & 268.23 & 7.87 & 8.16 & 17.00 & 1.53 & 42.41 \\
\hline 3 & 399.33 & 8.18 & 9.34 & 26.55 & 1.46 & 44.74 \\
\hline 4 & 255.33 & 7.53 & 8.27 & 24.44 & 1.36 & 48.67 \\
\hline 5 & 370.50 & 6.35 & 6.81 & 26.82 & 1.28 & 51.86 \\
\hline 6 & 887.67 & 7.62 & 8.82 & 26.00 & 1.43 & 46.11 \\
\hline 7 & 350.00 & 7.81 & 9.05 & 26.41 & 1.40 & 47.13 \\
\hline 8 & 1377.75 & 8.05 & 9.44 & 26.11 & 1.36 & 48.82 \\
\hline 9 & 2111.83 & 7.98 & 8.99 & 27.13 & 1.42 & 46.41 \\
\hline 10 & 667.00 & 7.70 & 8.89 & 25.97 & 1.48 & 44.11 \\
\hline 11 & 49.37 & 6.32 & 7.24 & 28.31 & 1.39 & 47.61 \\
\hline
\end{tabular}

The EC values were also higher around the landfill than the control profile with the eastern corner having the highest values. This is indicative of a high concentration of total dissolved salts (Ekosse, 2000), which in turn suggests that a contaminant plume from the landfill flows towards the eastern corner. Previous geophysical investigations carried out at the Gaborone landfill area by Bogatsu et al., (2000) confirmed the existence of a contaminant plume along its eastern corner. Furthermore, in semi - arid regions such as Botswana, salts would be precipitated in the surface horizons of the soil due to a high rate of evapo-transpiration. The increase in $\mathrm{pH}$ and EC values with depth around the landfill indicates downward movement of ions especially along $\mathrm{P} 8$ and $\mathrm{P}$ 9. The lowest CEC value was recorded along $\mathrm{P}$ 2 while P 9 and P 11 had the highest (Table 1). P 1 had CEC values lower than those around the landfill (Table 1). The CEC of sediments is related to the PSD, SSA, mineral composition and $\mathrm{pH}$ of the sediments (Alloway and Ayres, 1997; Sparks, 1995). A low wt \% clay and SSA of the sediments may explain the low CEC values observed. The small SSA may have caused a low surface charge density, offering little opportunity for ionic exchange within the sediments (Sparks, 1995). XRPD analyses revealed quartz, hematite, muscovite, plagioclase and microcline to be contained in the saprolite and quartz, muscovite, albite, microcline, and kaolinite in the whole soil (Figure 3). Quartz and microcline were the 
dominant mineral phases whereas kaolinite was minor. The dominant mineral phases in the clay fraction were quartz and kaolinite whereas smectite occurred in minor and/ or trace quantities along all the profiles (Figure 4).

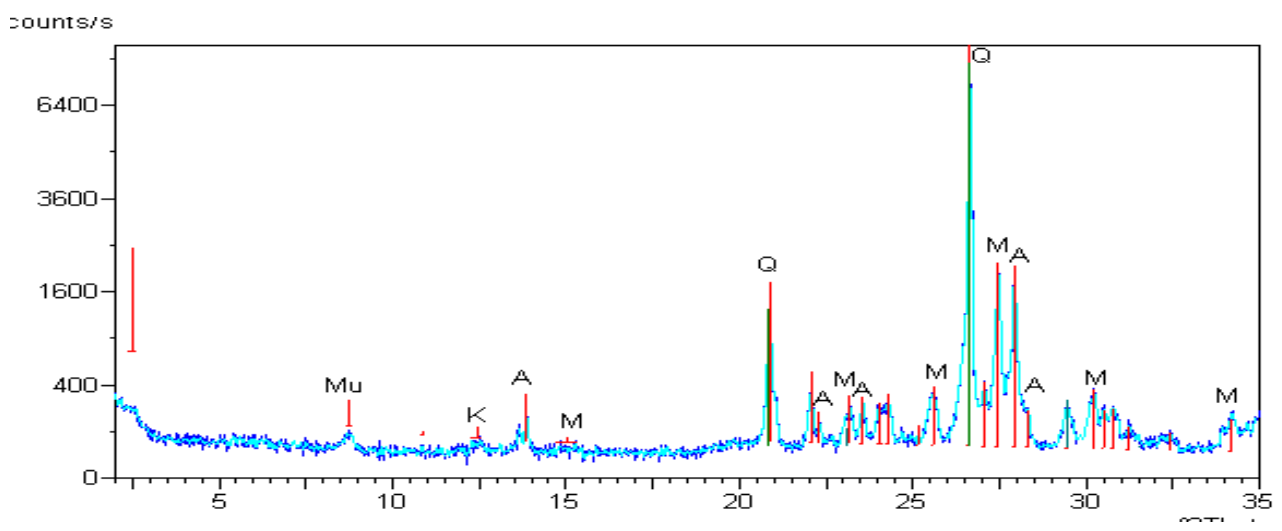

Fig 3: XRPD Diffraction pattern of a representative bulk subsurface sediment sample from the Landfill showing muscovite, kaolinite (K), albite (A), microcline (M), muscovite $(\mathrm{Mu})$, and quartz $(\mathrm{Q})$ peaks

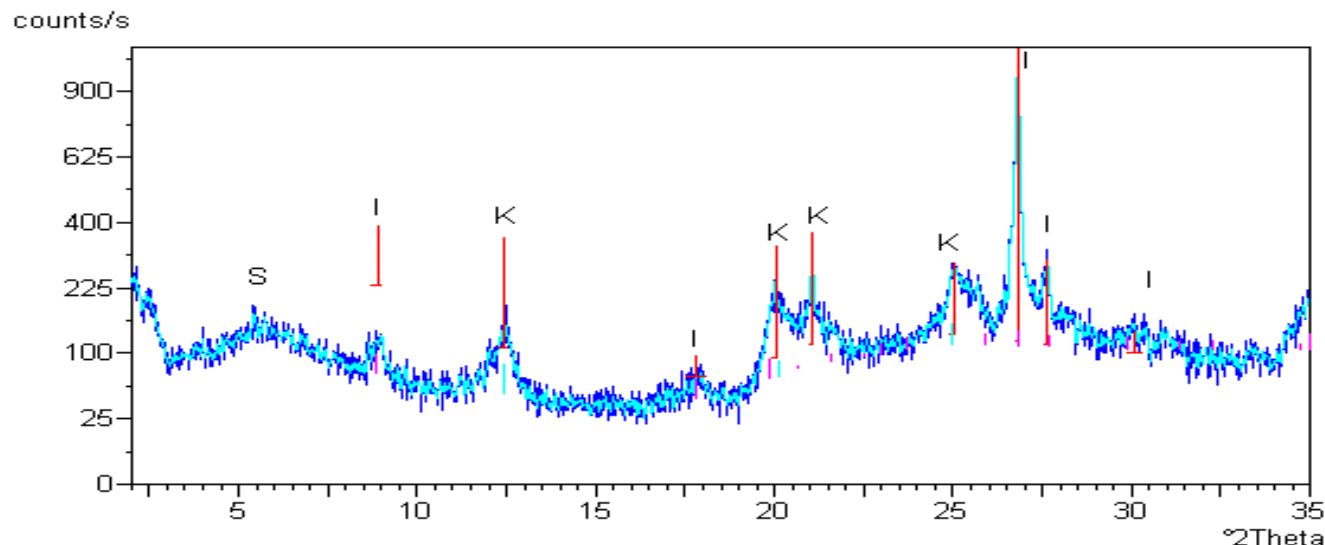

Fig 4: Typical XRPD diffractogram of the clay fraction of a representative subsurface sample from the landfill area showing smectite, illite, and kaolinite peaks. $(I=$ illite, $K=$ kaolinite, $S=$ smectite. $)$

Illite was identified as a major mineral phase in samples from $\mathrm{P}$ 8, as a minor mineral phase in samples from $\mathrm{P} 7$ and $\mathrm{P} 9$, and as trace in samples from $\mathrm{P} 1, \mathrm{P} 2, \mathrm{P} 3, \mathrm{P} 4, \mathrm{P}$ 5, P 6, P 10 and P11.. Calcite was identified in samples from $\mathrm{P} 2, \mathrm{P} 3$, and $\mathrm{P}$ 6. Although natural phenomena are mainly responsible for the alteration of the feldspars and micas to kaolinite and smectites (Faure, 1997), leachate migration could have played a contributory role. Illite formation occurs as a result of incomplete loss of $\mathrm{K}^{+}$from the K-feldspars-muscovite-kaolinite alteration system (Pickering and Murray, 1995). Kaolinite minerals, which dominate the mineral composition of the sediments posses a small external surface, which limits its adsorptive properties. In addition it is inert over a wide range of acid / alkali $\mathrm{pH}$ which further reduces its adsorptive capacity. The sediments will therefore have a reduced ability to adsorb contaminants from the leachate plume because of the dominance of chemically inert soil minerals.
The prevailing moist environment, the abundant $\mathrm{CO}_{3}{ }^{2-}$ in landfill leachate (Christensen et al., 1994) and the alkaline conditions in the subsurface environment around the landfill is likely to encourage the precipitation of $\mathrm{CaCO}_{3}$ as observed along $\mathrm{P} 2, \mathrm{P} 3$ and P 6.

The physicochemical and mineralogical properties of the subsurface sediments around the Gaborone Landfill area offer a poor ability to adsorb contaminants from any plume migrating from the landfill. Though the high $\mathrm{pH}$ of these sediments is likely to result in precipitation of some ionic contaminants, there is a likelihood of contaminants seeping through the soil layer into surrounding groundwater resources in the vicinity of the landfill due to the porous nature of subsurface deposits. The mineral composition does not favor the attenuation of contaminants within the sediment because of the dominance of chemically inert minerals. This study 
suggests the installation of remediation measures such as a leachate drainage and collection system to reduce its seepage into the surrounding environment. Monitoring of the water quality in the surrounding surface and groundwater resources is recommended as environmental health hazard measures.

\section{REFERENCES}

Alloway, B. J., and Ayres, D. C., (1997). Chemical principles of environmental pollution. Blackie Academic \& Professional Glasgow London

Arup Botswana, (1994). Gaborone solid Waste Disposal site development plan. Arup Botswana

Bogatsu, Y., Atekwana, E., Ekosse, G., Atekwana, E., Totolo, O., (2000). Hydrogeochemical impacts of the

Gaborone Landfill on its surrounding subsurface environments. Botswana Notes and Records 32, 159-164

Brady, N. C., Weil, R. R., (1999). The nature and properties of soils $12^{\text {th }}$ Edition. Prentice Hall New Jersey

Christensen, T. H., Kjeldsen, P., Albechsten, H. J., Heron, G., Nielsen, H. P., Bjerg, L.P. Holm, P. E., (1994). Attenuation of Landfill Leachate Pollutants in Aquifers. Critical Reviews in Environmental Science and Technology 24(2), $119-202$

Christensen, T. H., Lehmann, N., Jackson, T., Holm, P. E., (1996). Cadmium and Nickel distribution

coefficient for sandy aquifer materials. Journal of Contaminant hydrology 24, $24-84$.

Ekosse, G. E., (2000). The Makoro kaolin deposit, southeastern Botswana: Its genesis and possible industrial applications. Applied Clay Science 16, $301-320$.

Faure, G., (1997). Clay minerals. Principles and applications of geochemistry. Prentice Hall, New Jersey USA.

Hendershot, W. H., Duquette, M., (1986). A simple Barium chloride method for determining cation exchange capacity and exchangeable cations. Soil Science Society of America Journal 50, 605 - 608

Igwe, C. A., Akamigbo, F. O. R., Mbagwo, J. S. C., (1999). Chemical and mineralogical properties of soils in southeastern Nigeria in relation to aggregate stability. Geoderma 92, 111 - 123.
Ma, C. and Eggleton, R. A., (1999). Cation exchange capacity of kaolinite. Clays and Clay Minerals 47 (2), $174-180$.

Melkerud, P. A., Bain, D. C., Jongmans, A. G., Tarvainen, T., (2000). Chemical, mineralogical and morphological characterization of trace podzols developed on glacial deposits in Northern Europe. Geoderma 94, 125 - 148

Ngole, V., Totolo, O., Ekosse, G., (2002). Granulometric characterization of subsurface sediments around the Gaborone Lanfill area, Botswana. Botswana Journal of Technology 2(11), 46-53

Okalebo, J. R., Gathua, K. W., and Woomer, P. L., (1993). Laboratory methods of soil and plant analysis. A working manual. Soil Science Society of East Africa (SSSEA) Technical publication 1, $88 \mathrm{pp}$.

Pickering, S. M. and Murray, H. H., (1995). Clays. Industrial Minerals and rocks. Society of mining engineers.

Ringrose, S., Sefe, F., Ekosse, G., (1995). Progress towards the evaluation of desertification in Botswana. Desertification Control Bulletin 27, 62-168

Rushbrook, P., (1997). Encouraging better landfilling in middle and lower income countries. $6^{\text {th }}$ International Landfill Symposium, Sardinia Italy 1997. Proceedings Sardinia 1997.

Sparks, L. D., (1995). Ion exchange processes. Environmental soil chemistry. Academic press London.

Tan, K. H ., (1996). Soil sampling, preparation and analyses. Marcel Dekker, Inc. New York.

Thornton, S. F., Tellam, J. H., Lerner, D. N., (2000). Attenuation of landfill leachate by UK Triassic sandstone aquifer materials 1 . Fate of inorganic pollutants in laboratory columns. Journal of contaminant Hydrology 43, 327 - 354.

Van Reeuwijk, L. P., (1993). Procedures for Soil Analysis, International Soil Reference and Information Center (ISRIC) Technical paper, no. 9. ISRIC, $19 \mathrm{pp}$

Wilcke, W., Kaupenjohann, M., (1994). Small-scale heterogeneity of soil chemical properties. II) Fractions of aluminum and heavy metals. Angenommen 1, 459 - 465 